\section{Dissimilatory Reduction of Sulfate in Black Layer}

\author{
W.L. Berndt ${ }^{1}$ \\ Division of Professional and Technical Studies, Edison College, 8099 College \\ Parkway S.W., P.O. Box 60210, Building C-101, Fort Myers, FL 33906-6210
}

Joseph M. Vargas, Jr.

Department of Botany and Plant Pathology, 102 Pesticide Research Center, Michigan State Univ., East Lansing, MI 48824

Additional index words. creeping bentgrass, redox potential, sulfate-reducing bacteria, sulfide, sulfur

\begin{abstract}
Black layer has been associated with a severe decline in the quality of turf on putting greens. It was suggested that the black layer results from dissimilatory sulfate $\left(\mathrm{SO}_{4}{ }^{2-}\right)$ reduction. This study was done to determine if $\mathrm{SO}_{4}{ }^{2-}$ reduction occurs in an existing black layer. Radioactive ${ }^{35} \mathrm{SO}_{4}^{2-}$ was used to calculate the rate of $\mathrm{SO}_{4}^{2-}$ reduction in intact soil cores taken from an existing black layer in a 'Penncross' creeping bentgrass (Agrostis palustris Huds. 'Penncross') putting green. When $10^{-3} \mathrm{M}^{35} \mathrm{SO}_{4}{ }^{2-}$ with a specific activity of $1.554 \times 10^{5} \mathrm{~Bq} \cdot \mathrm{mg}^{-1} \mathrm{SO}_{4}{ }^{2-}$ was injected into a core it reduced to sulfide $\left({ }^{35} \mathrm{~S}^{2-}\right)$ at a mean rate of $7.1 \mathrm{nmol}$ sulfur $(\mathrm{S}) / \mathrm{cm}^{3}$ soil/d. Injecting azide $\left(\mathrm{N}_{3}^{-}\right)$or molybdate $\left(\mathrm{MoO}_{4}{ }^{2-}\right)$ at $10 \%$ w/v with the label reduced the rate of $\mathrm{SO}_{4}{ }^{2-}$ reduction to 0.03 and $0.01 \mathrm{nmol} \mathrm{S} / \mathrm{cm}^{3} \mathrm{soil} / \mathrm{d}$, respectively. The effect of $\mathrm{N}_{3}{ }^{-}$confirmed that reduction of $\mathrm{SO}_{4}{ }^{2-}$ was biological, while the effect of $\mathrm{MoO}_{4}^{2-}$ confirmed that the entities responsible for the reductive cycling were sulfate-reducing bacteria (SRBs). This was the first proof that biological reduction of $\mathrm{SO}_{4}{ }^{2-}$ produces $\mathrm{S}^{2-}$ in a black layer from a creeping bentgrass putting green. It was concluded that the respiration of indigenous SRBs was linked to development of this black layer. Thus, a key to successfully controlling black layer in putting greens must involve regulating the respiratory activities of SRBs.
\end{abstract}

Black layer is the term for a condition in which the rootzone soil in putting greens turns black. Sometimes the entire soil profile is blackened uniformly. Other times, a black band of variable thickness and location in the profile is observed. Alternatively, black flecks of variable size can also be observed. Regardless of style, a decline in the quality of the turf frequently accompanies the onset of black layer. Turf decline symptoms range from a bronzing and/or thinning of turf to loss, which impacts the functional quality and visual integrity of an affected green. Because of its impact on turfgrass quality, black layer was said to be the number one problem of creeping bentgrass (Agrostis palustris Huds.) greens in the late 1980s (Scott, 1986). It was also said that the origin, nature, and mechanism of its formation are not very well understood (Smiley et al., 1992).

Blackening of soil was attributed to the accrual of metal sulfides (MeS) such as manganese sulfide $(\mathrm{MnS})$ or iron sulfide $(\mathrm{FeS})$ (Berndt and Vargas, 1987; Rankin, 1988). Berndt (1990) spot tested the black layers from various golf greens for the presence of $\mathrm{MeS}$ using a solution of sodium azide $\left(\mathrm{NaN}_{3}\right)$ and iodine $\left(\mathrm{I}_{2}\right)$ as described by Fiegel (1972). All the samples analyzed tested positive for the presence of MeS. The black layers that were examined exhibited a foul odor and loss of

Received for publication 7 Dec. 2005. Accepted for publication 23 Jan. 2006.

${ }^{1}$ To whom reprint requests should be addressed; e-maillberndt@edison.edu. the blackened condition with exposure to air. Some but not all were associated with severe turf decline. Experimental black layers created by adding elemental sulfur $\left(\mathrm{S}^{0}\right)$ to a waterlogged sand also tested positive for the presence of with natural black layers, the experimental black layers were associated with a foul odor and loss of the blackened condition with exposure to air.

Metal sulfides readily form when hydrogen sulfide $\left(\mathrm{HS}^{-}\right)$is released to the soil (Atlas and Bartha, 1980). For example, $\propto-\mathrm{FeS}$ (trolite) forms at $p e+\mathrm{pH}=5.63+0.12 \log \mathrm{SO}_{4}{ }^{2-}-0.23$ $\mathrm{pH}$ (Lindsay, 1979) provided sufficient $\mathrm{HS}^{-}$and iron II $\left(\mathrm{Fe}^{2+}\right)$ are available:

$\begin{array}{ll}\mathrm{HS}^{-} \rightarrow \mathrm{H}^{+}+\mathrm{S}^{2-} & \mathrm{pK}=12.90 \\ \mathrm{~S}^{2-}+\mathrm{Fe}^{2+} \rightarrow \propto-\mathrm{FeS} & \mathrm{pK}=16.21\end{array}$

There are two pathways by which $\mathrm{HS}^{-}$becomes available in soils (Paul and Clark, 1996). They are the anaerobic mineralization of organic $\mathrm{S}$ and the dissimilatory reduction of inorganic S. The mineralization of organic $S$ occurs via sulfatase enzymes occurring in fungi and bacteria. Dissimilatory reduction of inorganic $\mathrm{S}$ occurs via the respiratory activities of sulfate-reducing bacteria (SRBs) where compounds like $\mathrm{SO}_{4}^{2-}$ are used as terminal electron $\left(e^{-}\right)$acceptors.

It was assumed but never proven that the dissimilatory reduction of inorganic $\mathrm{S}$ was the pathway by which most black layers formed (Berndt and Vargas, 1987; Berndt et al., 1987). One reason for this was that when $\mathrm{S}^{0}$ was applied to putting greens it was often linked to severe outbreaks of black layer. Incidents of MeS (Berndt et al, 1987; Berndt, 1990). As severe black layer were also associated with high levels of $\mathrm{SO}_{4}^{2-}$ in irrigation water. Several other research reports (Burpee and Anderson, 1987; Gockel 1987; Goss, 1987; Rankin, 1988; Smith, 1988) professed but did not prove an association between the formation of black layer and dissimilatory $\mathrm{SO}_{4}^{2-}$ reduction. As early as 1974, suggestions were made linking the formation of black layer to the respiratory activities of SRBs like Desulfovibrio (Kozelnicky, 1987). Thus, the objective of the laboratory study described in this paper was to determine if dissimilatory $\mathrm{SO}_{4}{ }^{2-}$ reduction could be verified in a naturally occurring black layer from the rootzone of a creeping bentgrass putting green.

\section{Materials and Methods}

Carrier-free $\mathrm{Na}_{2}{ }^{35} \mathrm{SO}_{4}{ }^{2-}$ (New England Nuclear) was used in this experiment to calculate rates of $\mathrm{SO}_{4}{ }^{2-}$ reduction. The radioactive tracer was injected into intact cores taken from a black layer that was located in the rootzone of a creeping bentgrass putting green. The ${ }^{35} \mathrm{~S}^{2-}$ that formed was distilled from the soil and quantified via liquid scintillation counting. From that data rates of $\mathrm{SO}_{4}{ }^{2-}$ reduction were calculated.

Intact sample cores of black layer soil were collected from the rootzone of a 'Penncross' creeping bentgrass research putting green located at the Robert Hancock Turfgrass Research Center in East Lansing, MI. The rootzone was originally constructed as a modified soil (Beard, 1973) composed of $88.3 \%$ sand, $5.0 \%$ silt, and $6.7 \%$ clay as determined by the pipette method (Gee and Bauder, 1986). Soil cores had a moisture content of $10 \%$ by weight at the time of sampling as determined by gravimetry (Gardner, 1986). Air dried soil from 0 to $15 \mathrm{~cm}$ depth was $0.07 \% \mathrm{~N}$ as determined by Kjeldahl analysis (Bremner and Mulvaney, 1982) and $0.8 \% \mathrm{C}$ as determined by dry combustion (Nelson and Sommers, 1982) yielding an average $C: N$ of $11.4: 1$. The $\mathrm{SO}_{4}^{2-}$ concentration in air-dried soil (Tabatabai, 1974) averaged $33 \mu \mathrm{g} \mathrm{SO}_{4}^{2-} / \mathrm{cm}^{3}$ soil. Most probable number estimates of sulfate-reducing bacteria (Alexander, 1982) indicated an approximate concentration of between $3.3 \times$ $10^{3}$ and $7 \times 10^{5} \mathrm{SRBs} / \mathrm{g}$ soil.

The cores were collected by impaling plastic $10 \mathrm{~cm}^{3}$ syringe barrels with the ends cut away horizontally into an existing band-type black layer that was located $10 \mathrm{~cm}$ deep in the rootzone. This black layer was composed of an unknown form of MeS. This was confirmed by spot testing with a solution of $\mathrm{NaN}_{3}-\mathrm{I}_{2}$ as described by Feigl(1972). By this test, MeS was present in soil if bubbling occurred upon introducing soil into the $\mathrm{NaN}_{3}-\mathrm{I}_{2}$ s solution. Bubbling occurred because $\mathrm{MeS}$ catalyzes production of $\mathrm{NaI}$, with the evolution of $\mathrm{N}_{2}$ gas:

$2 \mathrm{NaN}_{3}+\mathrm{I}_{2} \stackrel{\mathrm{MeS}}{\longrightarrow} 2 \mathrm{NaI}+3 \mathrm{~N}_{2}$

Black layer soil cores were then capped with rubber stoppers and stored in an atmosphere of $90: 10 \mathrm{~N}_{2}: \mathrm{H}_{2}$ at ambient temperature in the dark until time for use. This was done to prevent oxidation of the MeS in the soil. Black layer was visible in each core used but was 


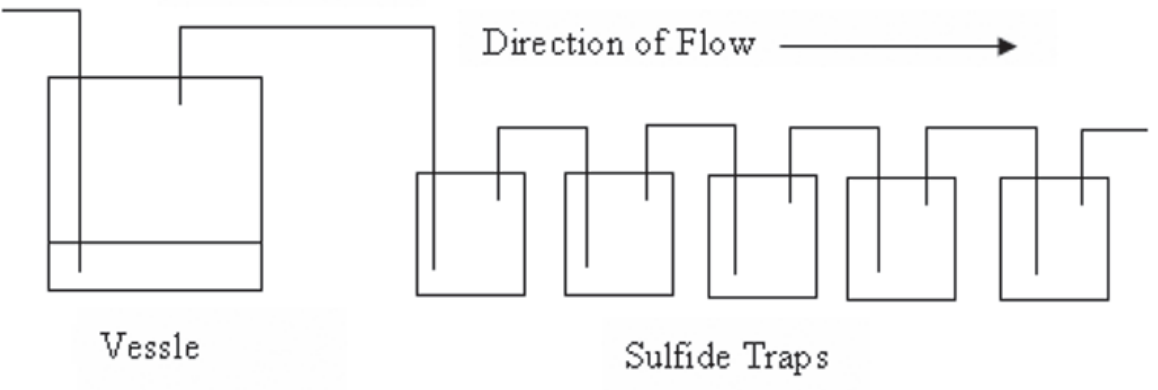

Fig. 1. Schematic design of the anaerobic $\mathrm{S}^{2-}$ still used to collect ${ }^{35} \mathrm{~S}^{2-}$. Oxygen-free $\mathrm{N}_{2}$ was used as the carrier gas, and $20-\mathrm{mL}$ glass screw-top liquid scintillation vials containing $3 \mathrm{~mL}$ anoxic $2 \% \mathrm{CdCl}_{2}$ were used for the $\mathrm{S}^{2-}$ traps. The $\mathrm{N}_{2}$ was deoxygenated by sparging over hot $\mathrm{Cu}^{2+}$ filings.

variable in appearance from core to core.

A tracer solution was prepared by introducing carrier-free $\mathrm{Na}_{2}{ }^{35} \mathrm{SO}_{4}$ (New England Nuclear) into $10^{-3} M \mathrm{Na}_{2} \mathrm{SO}_{4}$ to produce a $10^{-3} M$ stock solution of $\mathrm{Na}_{2}{ }^{35} \mathrm{SO}_{4}$. The tracer solution had an activity of $11,100 \mathrm{~Bq}$ per 0.5 $\mathrm{mL}$, which equated to a specific activity of $155,400 \mathrm{~Bq}$ per $\mathrm{mg} \mathrm{SO}_{4}{ }^{2-}$.

Two control solutions were then prepared by amending portions of the stock tracer with either sodium azide $\left(\mathrm{NaN}_{3}\right)$ or sodium molybdate $\left(\mathrm{Na}_{2} \mathrm{MoO}_{4}\right)$ to a final concentration of $10 \% \mathrm{w} / \mathrm{v}$. The controls were used to prevent reductive cycling from occurring. Azide $\left(\mathrm{N}_{3}{ }^{-}\right)$is a nonselective biocide which prevents the occurrence of respiratory electron transport (Smith et al., 1983), while $\mathrm{MoO}_{4}^{2-}$ is a competitive inhibitor of sulfate-reducing bacteria that is not toxic to other soil organisms (Smith, 1981).

Purging and then subsequently recovering ${ }^{35} \mathrm{~S}^{2-}$ from the soil was a basis for this study. To do so required the construction of an anaerobic still similar to the one described by Jorgensen and Fenchel (1974) and Smith (1981) (Fig. 1). The still consisted of a $200 \mathrm{~mL}$ wide-mouth screw top glass reaction vessel with a detachable lid. The lid was linked via port A to an upstream source of $\mathrm{O}_{2}$-free $\mathrm{N}_{2}$, and via port $\mathrm{B}$ to a downstream series of ${ }^{35} \mathrm{~S}^{2-}$ traps. The traps were $20 \mathrm{~mL}$ glass scintillation vials containing $3 \mathrm{~mL}$ of anoxic $2 \% \mathrm{CdCl}_{2}$ connected in series via glass tubing. All line connections were made directly to vial caps so that the traps could be changed as required. The trapping train terminated into a $125 \mathrm{~mL}$ Erlenmeyer flask containing $100 \mathrm{~mL} 2 \% \mathrm{CdCl}_{2}$ to ensure complete recovery of all ${ }^{35} \mathrm{~S}^{2-}$ during distillation. A third port in the lid was fitted with a rubber septum to facilitate entry into the reaction vessel as necessary.

For the experiment $11,100 \mathrm{~Bq}$ of stock tracer was injected into the center of each of 3 soil cores using a $1-\mathrm{cm}^{3}$ syringe fitted with a 3.8 $\mathrm{cm} 22$ ga needle. Each of the cores was then sealed using rubber stoppers and incubated in an 90:10 atmosphere of $\mathrm{N}_{2}: \mathrm{H}_{2}$ at $23{ }^{\circ} \mathrm{C}$ in the dark for $48 \mathrm{~h}$.

After the incubation period, one of the cores was removed from its syringe barrel and placed in the reaction vessel. The lid was attached, traps containing $3 \mathrm{~mL}$ of $2 \% \mathrm{CdCl}_{2}$ were installed, and then the vessel and trapping train were purged with $\mathrm{O}_{2}$-free $\mathrm{N}_{2}$ for 1 min. Next,
$20 \mathrm{~mL}$ of freshly boiled distilled $\mathrm{H}_{2} \mathrm{O}$ cooled to room temperature under an atmosphere of $\mathrm{N}_{2}$ was added to the vessel to help disperse the soil core. The flow rate of the $\mathrm{O}_{2}$-free $\mathrm{N}_{2}$ was then adjusted to $100 \mathrm{~cm}^{3} \cdot \mathrm{min}^{-1}$. This process was repeated for each sample core. This phase of the distillation process collected gaseous or water soluble $\mathrm{H}^{35} \mathrm{~S}^{-}$.

After $30 \mathrm{~min}$, the gas flow was halted, the first set of traps were removed, and then fresh traps were installed. Two milliliters of anoxic $37 \% \mathrm{HCl}$ was then injected into the vessel to reduce solution $\mathrm{pH}$ to 1 to 2 . The flow rate of the $\mathrm{O}_{2}$-free $\mathrm{N}_{2}$ was again adjusted to 100 $\mathrm{cm}^{3} \cdot \mathrm{min}^{-1}$, and the distillation process was continued for another $30 \mathrm{~min}$. Then, the gas flow was halted and the second set of traps was removed. This process was repeated for each sample core. This phase of the distillation process collected precipitated ${ }^{35} \mathrm{~S}^{2-}$ that was volatile in acid.

For each ${ }^{35} \mathrm{~S}^{2-}$ trap $15 \mathrm{~mL}$ of liquid scintillation counting (LSC) cocktail for aqueous solutions (RPI, Mt Prospect, Ill.) was added directly. The radioactivity distilled into each trap was then determined by counting in a Beckman (Fullerton, Calif.) LS 8100 scintillation counter. All samples were corrected for quenching by the H\# method (Beckman, Fullerton, Calif.). Rates of $\mathrm{SO}_{4}^{2-}$ reduction were then calculated using the following formula from Sorokin, (1962):

$$
\frac{\left(\left[\mathrm{SO}_{4}{ }^{2-}\right]\right)(\mathrm{a})(1.06)}{(\mathrm{A})(\mathrm{V})(\mathrm{t})}=\text { nmols } \mathrm{S} \mathrm{cm}^{-3} \mathrm{~d}^{-1}
$$

where $\left[\mathrm{SO}_{4}{ }^{2-}\right]$ is the concentration of $\mathrm{SO}_{4}{ }^{2-}$ in $\mathrm{nmol} \cdot \mathrm{cm}^{-3}$, (a) is the total number of $\mu \mathrm{Ci}$ of $\mathrm{H}_{2}^{35} \mathrm{~S}$ plus $\mathrm{Me}^{35} \mathrm{~S}, 1.06$ is an isotope correction factor for the microbial fractionation of ${ }^{32} \mathrm{~S}$ and ${ }^{35} \mathrm{~S}$ isotopes used by both Jorgensen and Fenchel, (1974) and Sorokin, (1962), (A) is the original amount of radioactivity in $\mu \mathrm{Ci}$ added, $(\mathrm{V})$ is the soil volume in $\mathrm{cm}^{3}$, and (t) is the incubation time. The mean residence time $\left(\mathrm{T}_{\mathrm{mrt}}\right)$ of the $\mathrm{SO}_{4}{ }^{2-}$ pool in the soil was calculated by dividing the initial $\left[\mathrm{SO}_{4}{ }^{2-}\right]$ by the calculated rate of $\mathrm{SO}_{4}^{2-}$ reduction. The residence half-life of the ${ }^{35} \mathrm{~S}$ label $\left(\mathrm{T}_{\text {rhl }}\right)$ was calculated by the formula $(\mathrm{A}) \div(\mathrm{a})(2)$.

Experimental controls were included in the study by using the modified tracer solutions as described above. For the controls, 11,100
Bq of ${ }^{35} \mathrm{~S}_{-} \mathrm{N}_{3}{ }^{-}$amended tracer was injected into the center of a set of three cores. Likewise, $11,100 \mathrm{~Bq}$ of ${ }^{35} \mathrm{~S}-\mathrm{MoO}_{4}{ }^{2-}$ amended tracer was injected into the center of a different set of three cores. Control cores were then subjected to the incubation and the distillation/counting process as described above.

Collected data was analyzed statistically as a completely random design with three treatments replicated three times. Means were separated using Duncan's multiple range test $(P \leq 0.05)$

\section{Results and Discussion}

Dissimilatory reduction of ${ }^{35} \mathrm{SO}_{4}^{2-}$ occurred in the intact black layer at rates varying between 3 and $14 \mathrm{nmol} \mathrm{S} / \mathrm{cm}^{3}$ soil $/ \mathrm{d}$ (Table 1.). As a result, $\mathrm{H}^{35} \mathrm{~S}^{-}$was released and an acid-volatile ${ }^{35} \mathrm{~S}^{2-}$ fraction subsequently formed and accrued. About $32 \%$ of the injected ${ }^{35} \mathrm{SO}_{4}{ }^{2-}$ reduced into ${ }^{35} \mathrm{~S}^{2-}$. Between 80 to $95 \%$ of the ${ }^{35} \mathrm{~S}^{2-}$ was in an acid-volatile fraction. This suggested that most of the HS- produced in this soil during reductive cycling bonded with divalent metals such as $\mathrm{Fe}^{2+}$ or $\mathrm{Mn}^{2+}$ forming an acid-volatile $\mathrm{MeS}$ precipitate.

While most of the $\mathrm{H}^{35} \mathrm{~S}^{-}$probably bonded with soilmetals about $5 \%$ to $15 \%$ was considered free. This implied that during reductive cycling some free $\mathrm{HS}^{-}$is present at any given time. Free HS $^{-}$could be a cause of the turf decline associated with black layer. It is a cell poison that prevents the reduction of cytochromes a-a during electron transport (Smith et al, 1983). This substance was shown to be highly toxic to creeping bentgrass (Berndt, 1990), and would likely be toxic to many kinds of rhizosphere organisms and animals.

The reduction of ${ }^{35} \mathrm{SO}_{4}{ }^{2-}$ in this study was a biological process performed by SRBs. This was evidenced by the effects that both $\mathrm{N}_{3}{ }^{-}$and $\mathrm{MoO}_{4}^{2-}$ had on rates of reduction. Azide curtailed the rate of $\mathrm{SO}_{4}^{2-}$ reduction by suffocating soil organisms nonselectively. As with $\mathrm{HS}^{-}$, the $\mathrm{N}_{3}{ }^{-}$prevents reduction of cytochromes $\mathrm{a}-\mathrm{a}_{3}$ during respiration (Smith, et al., 1983). Molybdate lowered the rate of $\mathrm{SO}_{4}^{2-}$ reduction because it competitively inhibited the activity of ATP-sulfurylase, found only in SRBs (Paul and Clark, 1996). The $\mathrm{MoO}_{4}{ }^{2-}$ blocked the first step in the sulfate-reduction pathway without affecting the respiratory systems of other soil organisms (Smith, 1981).

There are several environmental conditions that must be satisfied before $\mathrm{SO}_{4}^{2-}$ is biologically reduced to $\mathrm{HS}^{-}$in soil. First, an adequate population of SRBs must be present. Sulfate-reducing bacteria are anaerobic bacteria that are found in many soils over a wide range of environmental conditions (Paul and Clark, 1996). Dissimilatory $\mathrm{SO}_{4}^{2-}$ reduction is now recognized in a large number of bacterial genera including Desulfovibrio, Desulfococcus, Desulfomonas, and Desulfobacter (Paul and Clark, 1996). While specific species of SRBs were not determined population estimates in the experimental soil were between $3.3 \times 10^{3}$ to $7 \times 10^{5} \mathrm{SRBs} / \mathrm{g}$ soil. The indigenous population of SRBs in this black layerwas apparently sufficient to reduce $\mathrm{SO}_{4}{ }^{2-}$ at rates comparable to those calculated for marine sediments located in the Black Sea, the Bay of 
Table 1. Mean rates of dissimilatory ${ }^{35} \mathrm{SO}_{4}^{2-}$ reduction in intact soil cores taken from the rootzone of a 'Penncross' creeping bentgrass putting green.

\begin{tabular}{|c|c|c|c|c|c|}
\hline Treatment & $\begin{array}{c}\mathrm{S}^{2-} \\
\text { Fraction }^{\mathrm{z}}\end{array}$ & $\begin{array}{c}\mathrm{Bq}^{35} \mathrm{~S}^{2-} \\
\text { Recovered }\end{array}$ & Rate $^{y}$ & $\mathrm{~T}_{\mathrm{mrt}}^{\mathrm{x}}$ & $\mathrm{T}_{\mathrm{rhl}}^{\mathrm{w}}$ \\
\hline${ }^{35} \mathrm{SO}_{4}^{2-}$ & $\begin{array}{l}\mathrm{H}^{35} \mathrm{~S}^{-} \\
\mathrm{Me}^{35} \mathrm{~S}\end{array}$ & $\begin{array}{r}162.80 \mathrm{~b}^{v} \\
3,503.90 \mathrm{a}\end{array}$ & $7.10 \mathrm{a}$ & $71.1 \mathrm{c}$ & $2.1 \mathrm{c}$ \\
\hline${ }^{35} \mathrm{SO}_{4}{ }^{2-}+\mathrm{NaN}_{3}$ & $\begin{array}{l}\mathrm{H}^{35} \mathrm{~S}^{-} \\
\mathrm{Me}^{35} \mathrm{~S}\end{array}$ & $\begin{array}{l}1.49 \mathrm{c} \\
5.14 \mathrm{c}\end{array}$ & $0.03 \mathrm{~b}$ & $15,696.8 \mathrm{~b}$ & $831.9 \mathrm{~b}$ \\
\hline${ }^{35} \mathrm{SO}_{4}^{2-}+\mathrm{Na}_{2} \mathrm{MoO}_{4}$ & $\begin{array}{l}\mathrm{H}^{35} \mathrm{~S}^{-} \\
\mathrm{Me}^{35} \mathrm{~S}\end{array}$ & $\begin{array}{l}0.81 \mathrm{c} \\
1.85 \mathrm{c}\end{array}$ & $0.01 \mathrm{c}$ & $39,870.0 \mathrm{a}$ & $2,090.3 \mathrm{a}$ \\
\hline
\end{tabular}

${ }^{2}$ Sulfide fraction recovered as hydrogen sulfide $\left(\mathrm{H}^{35} \mathrm{~S}\right)$ or acid-volatile metal sulfide $\left(\mathrm{Me}^{35} \mathrm{~S}\right)$.

y Rate of dissimilatory $\mathrm{SO}_{4}^{2-}$ reduction in $\mathrm{nmol} \mathrm{S} / \mathrm{cm}^{3} / \mathrm{soil} / \mathrm{d}$.

${ }^{x}$ Residence time of the $\mathrm{SO}_{4}{ }^{2-}$ pool in days.

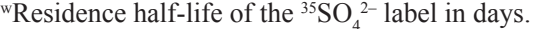

${ }^{v}$ Any two means within a column not followed by same letter are significantly different by Duncan's multiple range test at $P \leq 0.05$.

Keil, and the St. Barbara Basin (Jorgensen and Fenchel, 1974).

In addition to having an ample population of SRBs there must be an adequate supply of soil organic matter $(\mathrm{OM})$ and $\mathrm{SO}_{4}{ }^{2-}$ or some other form of inorganic $\mathrm{S}$ such as $\mathrm{S}^{0}$ (Berndt and Vargas, 1992). The OM is food for the bacteria and is the ultimate source of the electrons that drive the reduction of $\mathrm{SO}_{4}^{2-}$. Low molecular weight organic acids, alcohols, and molecular hydrogen $\left(\mathrm{H}_{2}\right)$ are also used as electron donors (Paul and Clark, 1996). In turn, inorganic S of some form is the electron acceptor for SRBs. If either OM or inorganic $\mathrm{S}$ is absent then SRB respiration does not occur, $\mathrm{HS}^{-}$is not produced, and MeS does not form (Berndt, 1990; Berndt and Vargas, 1992).

Perhaps the most important condition for the occurrence of $\mathrm{SO}_{4}{ }^{2-}$ reduction is a low redox potential (Connell and Patrick, 1968; Goldhaber and Kaplan 1975). Reduction of $\mathrm{SO}_{4}{ }^{2-}$ to $\mathrm{H}_{2} \mathrm{~S}$ theoretically occurs at an $E h^{\prime}=-0.21 \mathrm{v}$ as calculated by Berndt and Vargas (1996):

$\mathrm{SO}_{4}^{2-}+4 \mathrm{H}_{2}+2 \mathrm{H}^{+} \leftrightarrow \mathrm{H}_{2} \mathrm{~S}+4 \mathrm{H}_{2} \mathrm{O}$

$\Delta \mathrm{G}_{\mathrm{r}}^{\prime}=+9.6^{2} \mathrm{Eh}^{\prime}=-0.21$

$\mathrm{pe}+\mathrm{pH}=5.21-1 / 8 \mathrm{pSO}_{4}^{2-}+1 / 8 \mathrm{pH}_{2} \mathrm{~S}-1 / 4 \mathrm{pH}$

Low redox potential is required for the process because most types of SRBs are obligate anaerobes that can be poisoned by traces of $\mathrm{O}_{2}$ (Atlas and Bartha, 1981; Paul and Clark, 1996). The redox potential of the experimental soil was not measured, but the fact that MeS formed in the soil before the study was evidence that suggested it was relatively low. This should be considered unique as coarse textured, reasonably well drained terrestrial soils like those found in golf putting greens usually have a high enough redox potential to avert reduction of $\mathrm{SO}_{4}{ }^{2-}$.

Lowering of redox potential in greens could occur when rates of microbial respiration are high, when rates of $\mathrm{O}_{2}$ diffusion are restricted, and/or when $\mathrm{O}_{2}$ scavengers like $\mathrm{S}^{0}$ or organic $\mathrm{N}$ are present (Berndt, 1990; Berndt and Vargas, 1992; Berndt and Vargas, 1996). It would seem logical, though, that each black layer situation should have its own set of particulars that are somehow related to low redox potential. For example, some black layers may develop as a result of the application of $\mathrm{S}^{0}$ to depress $\mathrm{pH}$ (Berndt, et al., 1987; Berndt, 1990). Oxidation of applied $\mathrm{S}^{0}$ represents an $\mathrm{O}_{2}$ sink that can create a low redox potential in soil, especially if organic carbon of some type is plentiful (Berndt and Vargas, 1992). Application of $\mathrm{S}^{0}$ also provides the soil with an abundance of inorganic molecules (i.e., $\mathrm{S}^{0}, \mathrm{SO}_{4}^{2-}$ ) that can function as $e^{-}$acceptors in reduction processes. Nitrification of applied organic $\mathrm{N}$ can lower redox potential by scavenging $\mathrm{O}_{2}$ thus allowing $\mathrm{HS}^{-}$to be released (Berndt, 1990). Alternatively, denitrification can also help to produce low redox conditions in turf soils by depleting $\mathrm{NO}_{3}^{-}$, provided that the concentration of $\mathrm{O}_{2}$ is also relatively low (Berndt, 1990; Berndt and Vargas, 1996). In other situations low redox conditions could result because of restricted $\mathrm{O}_{2}$ diffusion resulting from water-logging(Berndt, 1990), an accumulation of surface algae(s) as suggested by Hodges (1989), the presence of biofilms as suggested by Cullimore et al. (1990), or the development of a surface salt crust or internal soil layers (Berndt, 1990). Turnover of algal cells and biofilm constituents would also constitute an excellent source of donor electrons for the sulfate-reduction process.

This research proved that dissimilatory reduction of $\mathrm{SO}_{4}^{2-}$ was an active pathway for the release of $\mathrm{S}^{2-}$ in an existing black layer within a creeping bentgrass putting green. This research also proved that entities responsible for the reductive cycling were SRBs of unknown genera. Since dissimilatory $\mathrm{SO}_{4}^{2-}$ reduction is a bacterial respiration process (Berndt, 1990; Berndt et al., 1987; Berndt and Vargas, 1992; Berndt and Vargas, 1996) the key to successfully controlling the release of $\mathrm{S}^{2-}$ in putting green root zones via this process must therefore involve controlling the respiratory activities of SRBs. One way this might be accomplished is by poising soil redox potential at a point high enough to avert release of $\mathrm{S}^{2-}$ by introducing alternate $e^{-}$acceptors such as $\mathrm{NO}_{3}^{-}$(Berndt and Vargas, 1996), and by limiting the input of $e^{-}$acceptors such as $\mathrm{S}^{0}$ and $e^{-}$donors such as organic C (Berndt and Vargas, 1992).

\section{Literature Cited}

Alexander, M. 1982. Most probable number method for microbial populations, p. 815-820. In: A.L. Page (ed.). Methods of soil analysis. Part 2.2nded. Agron. Monogr. 9. ASA-SSSA, Madison, Wis.

Atlas, R.M., and R. Bartha. 1981. Microbial ecology: fundamentals and applications. Addison-Wesly, Reading, Mass.

Beard, J.B. 1973. Turfgrass: Science and culture. Prentice-Hall, Englewood Cliffs, N.J.

Berndt, W.L. 1990. Investigation into turfgrass black layer. PhD diss. Mich. State Univ., East Lansing.

Berndt, W.L., and J.M. Vargas, Jr. 1987. Etiology and impact of dissimilatory sulfate reduction in highly maintained turfgrass soils. Phytopathology 77(12): 1716

Berndt, W.L. and J.M. Vargas, Jr. 1992. Elemental sulfur lowers redox potential and produces sulfide in putting green sand. Hortscience 27(11):1188-1190.

Berndt, W.L. and J.M. Vargas, Jr. 1996. Preventing black layer with nitrate. J. Turfgrass Mgt. 1(4):11-22.

Berndt, W.L., J.M. Vargas, Jr., A.R. Detweiler, P.E. Rieke, and B.E. Branham. 1987. Black layer formation in highly maintained turfgrass soils. Golf Course Mgt. 55:106-112.

Bremner, J.M. and C.S. Mulvaney. 1982. Nitrogentotal, p. 595-624. In: A.L Page (ed.). Methods of soil analysis. Part 2. 2nd ed. Agron. Monogr. 9. ASA-SSSA, Madison, Wis.

Burpee, L.L. and A. Anderson. 1987. The cause of black layer in golf greens: An alternative hypothesis. Greenmaster 23:24.

Connell, W.E. and W.H. Patrick. 1968. Sulfate reduction in soil: Effects of redox potential and $\mathrm{pH}$. Sci. 159:86-87.

Cullimore, D.R., S. Nilson, S. Taylor, and K. Nelson. 1990. Structure of black plug layer in a turfgrass putting green sand. J. Soil Water Conserv. 45:657-659

Feigl, F. 1972. Spot tests in inorganic analysis. Elsevier, Amsterdam.

Gardner, W.H. 1986. Water content, p. 493-544. In: A. Klute (ed.). Methods of soil analysis. Part 1. 2nd ed. Agron. Monogr. 9. ASA-SSSA, Madison, Wis.

Gee, G.W. and J.W. Bauder. 1986. Particle size analysis, p. 383-409. In: A.L. Page (ed.). Methods of soil analysis. Part 2. 2nd ed. Agron. Monogr. 9. ASA-SSSA, Madison, Wis.

Gockel, J. 1987. Black layer: looking for light in all the right places. Golf Course Mgt. 55:26-32.

Goldhaber, M.B. and I.R. Kaplan. 1975. Controls and consequences of sulfate reduction in recent marine sediments. Soil Sci. 119(1):42-55.

Goss, R.L. 1987. Managing anaerobic soils. N.W. Turfgrass Topics 30:7.

Hodges, C.F. 1989. Another look at black layer. Golf Course Mgt. 57(3):54-58

Jorgensen, B. and T. Fenchel. 1974. The sulfur cycle of a marine sediment model system. Mar. Biol. 24:189-201.

Kozelnicky, G.M. 1987. Turf talk from the old Koz. Ga. Turfgrass News 20:3.

Lindsay, W.L. 1979. Chemical equilibria in soils. Wiley, New York.

Nelson, D.W. and L.E. Sommers. 1982. Total carbon, organic carbon, and organic matter, p. 539-577. In: A.L. Page (ed.). Methods of soil analysis. Part 2. 2nd ed. Agron. Monogr. 9. ASA-SSSA, Madison, Wis.

Paul,E.A. andF.E. Clark. 1996. Soil microbiology and biochemistry. Academic Press, New York, NY.

Rankin, P.C. 1988. When the black layer hit the fan. Turf Craft Aust. 6:18-20.

Scott, J. 1986. The black plague. Golf Course Mgt. 54:58-64.

Smiley, R.W., P.H. Dernoeden, and B.B. Clark. 1992. Compendium of turfgrass diseases. 2nd ed. APS Press, St. Paul, Minn.

Smith, J.D. 1988. Black plug layer on Sasketchewan golf courses. Greenmaster 24:6-21.

Smith, R. 1981. Sulfate reduction in the sediments of a eutropic lake. PhD diss. Mich. State Univ., East Lansing.

Smith, E. et al. 1983. Principles of biochemistry. McGraw-Hill, New York.

Sorokin, Y.I. 1962. Experimental investigation of bacterial sulfate reduction in the Black Sea using ${ }^{35} \mathrm{~S}$. Transl. Microbiol. 31:329-335.

Tabatabai, M.A. 1974. Determination of sulfate in water samples. Sulfur Inst. J. 10:11-13. 